\title{
Synthesis and Characterization of $\alpha-\mathrm{Fe}_{2} \mathrm{O}_{3}$ Nanoparticles by Microemulsion Method
}

\author{
Gamze BOZKURT ${ }^{1 *}$ \\ ${ }^{1}$ Project Coordination Implementation and Research Center, Erzurum Technical University
}

Geliş / Received: 24/05/2020, Kabul / Accepted: 30/08/2020

\begin{abstract}
In this study, $\alpha-\mathrm{Fe}_{2} \mathrm{O}_{3}$ nanoparticles (NPs) were synthesized by microemulsion method. Synthesized NPs were characterized by X-ray Diffraction (XRD), Thermogravimetric Analysis (TGA), Differential Scanning Calorimetry (DSC), Differential Thermal Analysis (DTA), Scanning Electron Microscopy (SEM), Fourier Transform Infrared (FTIR) spectra, and UV-Visible techniques. According to TGA analysis, it has been observed that a complete formation of $\mathrm{Fe}_{2} \mathrm{O}_{3}$ at around $400{ }^{\circ} \mathrm{C}$. According to SEM images, plate like structure formation was observed in $\alpha-\mathrm{Fe}_{2} \mathrm{O}_{3} \mathrm{NPs}$ with homogeneous dispersion. Approximately $13.1 \mathrm{~nm}$ particle size was calculated from the XRD data by using the Scherrer equation. Fe-O vibrations in octahedral and tetrahedral regions were obtained in the FTIR spectrum. According to UV-Vis spectrum, it was determined that NPs showed optical absorption feature at wavelength of around $420 \mathrm{~nm}$. In addition, optical band gap of the $\alpha-\mathrm{Fe}_{2} \mathrm{O}_{3}$ NPs was calculated $3.2 \mathrm{eV}$.
\end{abstract}

Keywords: $\alpha-\mathrm{Fe}_{2} \mathrm{O}_{3}$, microemulsion method, nanoparticle

\section{Mikroemülsiyon Yöntemi ile $\alpha-\mathrm{Fe}_{2} \mathrm{O}_{3}$ Nanopartiküllerinin Sentezi ve Karakterizasyonu}

Öz

$\mathrm{Bu}$ çalışmada $\alpha-\mathrm{Fe}_{2} \mathrm{O}_{3}$ nanopartiküller mikroemülsiyon yöntemi ile sentezlenmiştir. Sentezlenen nanopartiküller X-ışını difraksiyonu (XRD), Termogravimetrik Analiz (TGA), Diferansiyel Taramalı Kalorimetri (DSC), Diferansiyel Termal Analiz (DTA), Taramalı Elektron Mikroskobu (SEM), Fourier Dönüşümü Kızılötesi (FTIR) spektrumu ve UV-Görünür Bölge teknikleri ile karakterize edilmiştir. TGA analizine göre yaklaşık $400^{\circ} \mathrm{C}$ civarında tam bir $\mathrm{Fe}_{2} \mathrm{O}_{3}$ oluşumu gözlenmiştir. SEM görüntülerine göre, homojen dispersiyonlu $\alpha-\mathrm{Fe}_{2} \mathrm{O}_{3}$ nanopartiküllerde plaka benzeri yapı oluşumu gözlenmiştir. Scherrer denklemi kullanılarak, XRD verilerinden parçacık boyutu yaklaşık olarak $13.1 \mathrm{~nm}$ olarak hesaplanmıştır. FTIR spektrumundan ise oktahedral ve tetrahedral bölgelerde Fe-O titreşimleri elde edilmiştir. UV-Görünür bölge spektrumuna göre, NP'lerin yaklaşık olarak $420 \mathrm{~nm}$ dalga boyunda optik absorpsiyon özelliği sergilediği belirlenmiştir. Ek olarak, $\alpha-\mathrm{Fe}_{2} \mathrm{O}_{3} \mathrm{NP}^{\prime} l e r i n$ optik bant aralığı 3,2 eV olarak hesaplanmıştır.

Anahtar Kelimeler: $\alpha-\mathrm{Fe}_{2} \mathrm{O}_{3}$, mikroemülsiyon metodu, nanopartikül

1. Introduction

Nanomaterials with unique physical and chemical properties are synthesized using a variety of methods such as chemical reduction, photochemical reduction, electrodeposition, coprecipitation, spraypyrolysis, hydrothermal, and sol-gel. In recent years, the microemulsion method has been extensively investigated for the synthesis of 
nanomaterials as a method versatile, narrow size distribution, good dispersibility and repeatable method that gives control over the nanoparticle size (Pournajaf and Tabrizi, 2015; Pournajaf et al., 2014; Laokul et al., 2015; Chen et al., 2015a; Najjar et al., 2014, Chen et al., 2015b). Monodisperse nanoparticles can be prepared using simple apparatus at room conditions of temperature and pressure with the microemulsion method. So, the microemulsion method has been considered as an ideal method for synthesis inorganic materials (Sarkar et al. 2011; Han et al. 2015). Microemulsions are thermodynamically and isotropically stable dispersions consisting of at least three components as apolar phase (usually water), polar phase (usually oil) and surfactant (Pournajaf et al., 2014; Laokul et al.,2015; Sarkar et al. 2011). Microemulsions are two types as oil-in-water (O/W) or direct microemulsion method and water-in-oil (W/O) or reverse microemulsion method and the second compound is the dispersion medium or solvent. It is remarkable because of the water-in-oil / reverse microemulsion offers nanoparticle synthesis with narrow size distribution and controllable particle size (Shojaei et al., 2014; Foroughi et al., 2015; Strom et al., 2018). Thermodynamically stable dispersions, called reverse micelles, are composed of a continuous oil phase and a dispersed water droplet phase can be considered as true nanoreactors that can be used specifically to synthesize inorganic nanomaterials (Ye et al., 2018). In addition, reverse microemulsions exhibit self-assembly behaviour and this situation is very important for the synthesis of nanomaterials (Lai et al., 2019).

Surfactant molecules adsorb in interfaces and they reduce the interfacial tension and free energy. They are used to stabilize microemulsions by preventing the aggregation of nanoparticles (Sarkar et al., 2011; Shiri et al. 2019). Sodium bis (2ethylhexyl) sulfosuccinate (AOT), which is an anionic surfactant, can self-assemble into the reverse cylindrical and spherical micelles in various solvents. AOT is one of the surfactants commonly used in water-in-oil microemulsion systems (Lai et al., 2019; Shiri et al., 2019). By controlling the parameters of the microemulsion method, nanoparticles with different size and morphology can be obtained. These parameters are a) reactants concentration and type, $b$ ) process parameters such as $\mathrm{pH}$, temperature, stirring method and time (Beygi and Babakhani, 2017). The two water-soluble reactants are dissolved separately in two microemulsions. The resulting microemulsions are then mixed together and they provide the precipitation reaction to form in the aqueous core of the reverse micelles to form nanoparticles (Han et al., 2015).

Iron oxide $\left(\mathrm{Fe}_{2} \mathrm{O}_{3}\right)$ nanoparticle is an important metal oxide widely used in many fields such as catalysts (Koukabi et al., 2011), coatings (Lu et al., 2020), sensors (Wang et al., 2020), photocatalytic systems (Xiang et al., 2020) and drug delivery (Khokhlova 2016). $\mathrm{Fe}_{2} \mathrm{O}_{3}$ has four polymorphs consisting of $\alpha-\mathrm{Fe}_{2} \mathrm{O}_{3}, \beta-\mathrm{Fe}_{2} \mathrm{O}_{3}, \gamma-\mathrm{Fe}_{2} \mathrm{O}_{3}$ and $\varepsilon-\mathrm{Fe}_{2} \mathrm{O}_{3}$. Each polymorph has its specific crystal structure and physical properties. $\alpha-\mathrm{Fe}_{2} \mathrm{O}_{3}$ (hematite) is important among these polymorphs due to synthesis low toxicity, abundance, environmentally friendly nature, low cost, easy production and storage, high corrosion resistance, chemical inertness, biocompatibility and excellent substrate adhesion (Mirzaei et al., 2016). In addition, it is used in many areas mentioned above. 
In this study, $\alpha-\mathrm{Fe}_{2} \mathrm{O}_{3}$ nanoparticles (NPs) were synthesized with microemulsion method. Thermal, morphological, crystal structure and spectroscopic properties of the NPs were investigated. In addition, the optical absorption spectrum of the $\alpha-\mathrm{Fe}_{2} \mathrm{O}_{3} \mathrm{NP}$, and their optical absorption feature was investigated. Optical band gap of the $\alpha-\mathrm{Fe}_{2} \mathrm{O}_{3}$ NPs was calculated by using Tauc Equation.

\section{Material and Methods}

\subsection{Materials}

Iron (III) chloride $\left(\mathrm{FeCl}_{3}\right)$ obtained from Merck company was used as precursors. The surfactant dioctyl sulfosuccinate sodium salt (AOT), 1-butanol, n-heptane and sodium hydroxide $(\mathrm{NaOH})$ were purchased from Sigma-Aldrich Company in analytical grade. All experiments were performed by using deionized water.

\subsection{Synthesis of nanoparticles}

$\alpha-\mathrm{Fe}_{2} \mathrm{O}_{3}$ nanoparticles (NPs) were synthesized by water-in-oil (W/O) microemulsion composed of n-heptane as oil phase, anionic surfactant of AOT, co-surfactant of 1-butanol and precipitation agent as $\mathrm{NaOH}$ (Han et al., 2015; Khalili and Tabrizi, 2017). The selected $\mathrm{W}\left[\left(\mathrm{H}_{2} \mathrm{O}\right) /(\mathrm{AOT})\right]$ in molar ratio] value was 8 .

Two types microemulsion systems were prepared as microemulsion 1 and microemulsion 2. Firstly, a microemulsion solution prepared by dissolving AOT in 45 $\mathrm{mL}$-heptane and $5 \mathrm{~mL}$ 1-butanol. Then, microemulsion 1 was prepared by mixing the suitable amount of $0.58 \mathrm{M} \mathrm{NaOH}$ aqueous solution into the microemulsion solution. In the next system, suitable amount of $0.58 \mathrm{M}$ $\mathrm{FeCl}_{3}$ aqueous solution was mixed with a separate microemulsion solution to obtain the microemulsion 2 solution. Then, microemulsion 1 was added dropwise to microemulsion 2 and they were stirred for $1 \mathrm{~h}$ to form a precipitate. The mixture was filtered, washed with acetone and distilled water and then dried at room temperature. The sample were calcined at $500{ }^{\circ} \mathrm{C}$ for $2 \mathrm{~h}$ in the air atmosphere.

\subsection{Characterization}

Morphological properties of the NPs were determined by using Scanning Electron Microscope (SEM, Zeiss Sigma 300). X-ray diffraction (XRD) patterns were obtained using PANalytical Empyrean Instrument. Surface functional groups of the NPs were determined by using Fourier-transform infrared spectroscopy (FTIR, Bruker VERTEX 70v). Thermogravimetric analysis (TGA), Differential Scanning Calorimetry (DSC) and Differential Thermal Analysis (DTA) were studied in a Perkin Elmer STA 8000 in air atmosphere. The optical transmission/absorption spectra of the particles in deionized water were recorded using a Shimadzu UV-3600 Plus spectrometer.

\section{Results and Discussion}

Fig. 1 shows the TGA, DTG and DSC results. The weight loss observed in between 25 and $180{ }^{\circ} \mathrm{C}$ can be attributed to the removal of water. The chemical reactions during $\mathrm{Fe}_{2} \mathrm{O}_{3}$ formation are believed to be as following (Waseem et al., 2013);

$2 \mathrm{Fe}(\mathrm{OH})_{3} \longrightarrow 2 \mathrm{Fe}_{0.5}(\mathrm{OH})_{2}+\mathrm{H}_{2} \mathrm{O}$

$2 \mathrm{Fe}_{0.5}(\mathrm{OH})_{2} \longrightarrow 2 \mathrm{FeO}(\mathrm{OH})+2 \mathrm{H}_{2} \mathrm{O}$

$2 \mathrm{FeO}(\mathrm{OH}) \longrightarrow \mathrm{Fe}_{2} \mathrm{O}_{3}+3 \mathrm{H}_{2} \mathrm{O}$ 


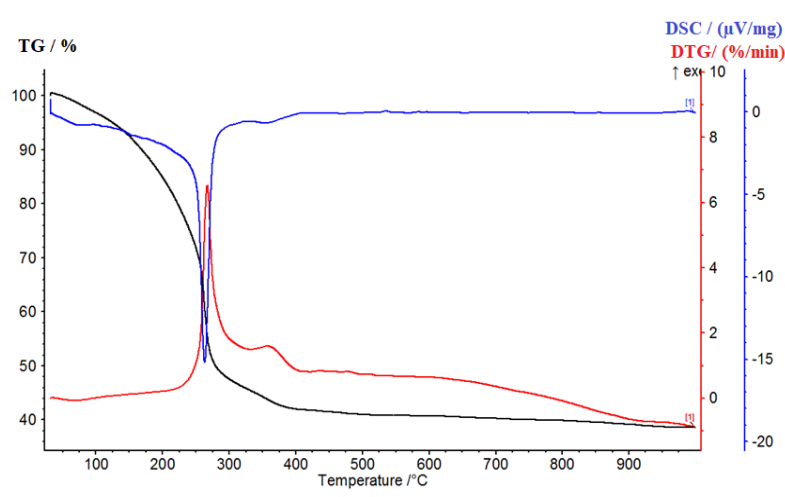

Figure 1. TGA, DTG and DSC results of uncalcined sample

It has been observed that a complete conversion of $\mathrm{Fe}(\mathrm{OH})_{3}$ to $\mathrm{Fe}_{2} \mathrm{O}_{3}$ up to $350{ }^{\circ} \mathrm{C}$ does not occur and still preserves several $\mathrm{OH}$ groups. According to DTG and DSC profiles, it has been observed two peaks associated with exothermic reactions at around 250 and $350{ }^{\circ} \mathrm{C}$. These peaks are related to the transformation of amorphous phase to crystalline $\mathrm{Fe}_{2} \mathrm{O}_{3}$ and its transformation to $\alpha$ $\mathrm{Fe}_{2} \mathrm{O}_{3}$, respectively (Waseem et al., 2013; Mirzaei et al., 2016).

According to XRD results in Fig. 2, characteristic diffraction peaks at $2 \theta$ values of $24.2^{\circ}, 33.2^{\circ}, 35.7^{\circ}, 41.1^{\circ}, 49.5^{\circ}, 54^{\circ}, 57.3^{\circ}$, $62.4^{\circ}$, and $64^{\circ}$ correspond to the (012), (104), (110), (113), (024), (116), (018), (214), and (300) planes of hexagonal $\alpha-\mathrm{Fe}_{2} \mathrm{O}_{3}$ were observed. The results indicated that the product are consisted of pure phases (Lin and Liaw 2015; Zainuri 2017; Kamali et al.,2014; Li et al., 2016). The particle size of the prepared $\mathrm{Fe}_{2} \mathrm{O}_{3}$ nanoparticles were calculated from the XRD data using the according to the following equation (i.e., Scherrer equation): (Patterson 1939).

$$
D=\frac{\mathrm{K} \cdot \lambda}{\mathrm{B} \cdot \cos \theta_{\mathrm{B}}}
$$

where $\mathrm{D}$ is average particle size, $\mathrm{K}$ is the Scherrer constant $(\mathrm{K}=0.9), \quad \lambda$ is the wavelength of radiation $\left(\lambda_{\mathrm{Cu}, \mathrm{K} \alpha}=0.154 \mathrm{~nm}\right)$, and $B$ is the integral breadth of peak (in radians $2 \theta$ ) located at angle $\theta_{B}$.

The (104) plane was selected to calculate the particle size $\alpha-\mathrm{Fe}_{2} \mathrm{O}_{3}$. It was found that the particle size of $\mathrm{Fe}_{2} \mathrm{O}_{3}$ is about $13.1 \mathrm{~nm}$. A particle size lower than that given in the literature was obtained (Kamali et al.,2014; Mirzaei et al., 2016; Li et al., 2016).

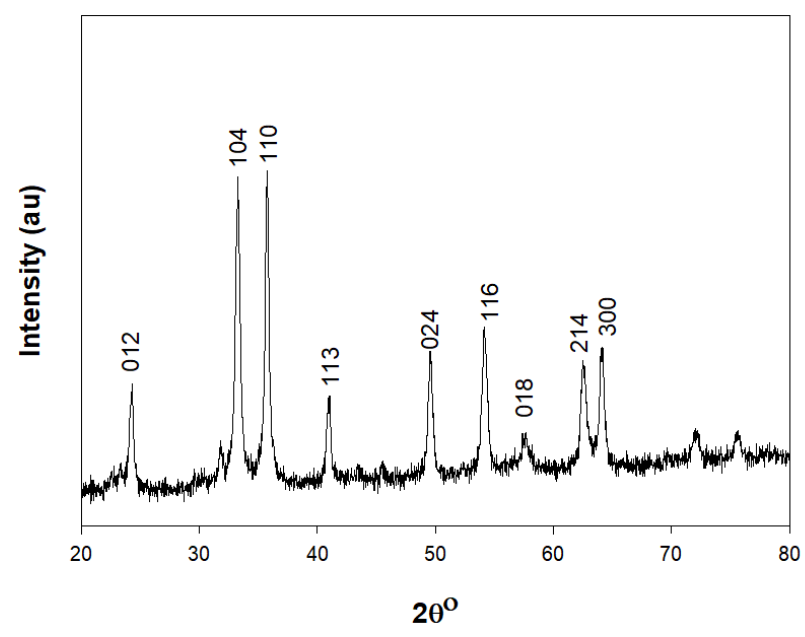

Figure 2. XRD pattern of $\alpha-\mathrm{Fe}_{2} \mathrm{O}_{3}$

According to FTIR spectra in Fig. 3, the bands at 1130,560 and $440 \mathrm{~cm}^{-1}$ correspond to characteristic features of $\alpha-\mathrm{Fe}_{2} \mathrm{O}_{3}$ and these peaks represent the metal oxygen stretching vibrational modes. The high frequency band at $560 \mathrm{~cm}^{-1}$ can be attributed to $\mathrm{Fe}-\mathrm{O}$ deformation in the octahedral and tetrahedral regions, while the low frequency band at 440 $\mathrm{cm}^{-1}$ can be related to the $\mathrm{Fe}-\mathrm{O}$ deformation in the octahedral region of hematite (Mirzaei et al., 2016; Li et al., 2016). 


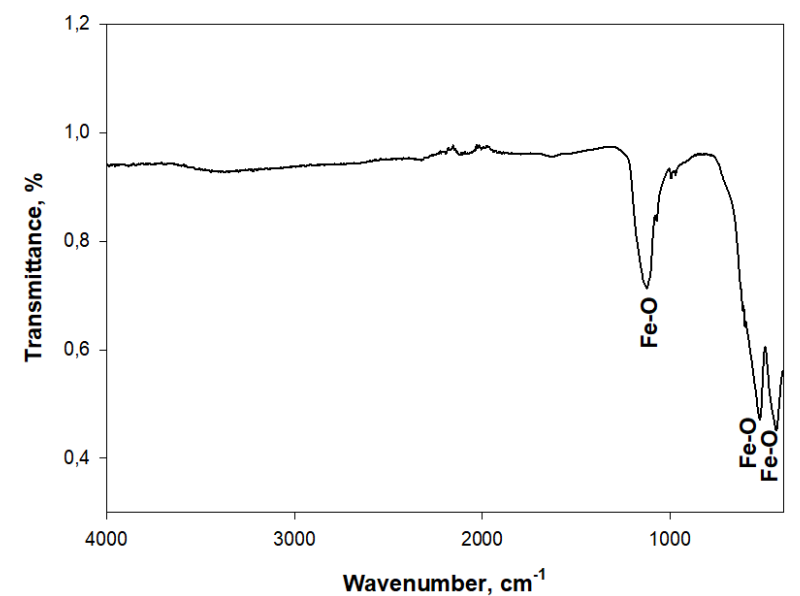

Figure 3. FTIR spectrum of $\alpha-\mathrm{Fe}_{2} \mathrm{O}_{3}$

The SEM images of the NPs are given in Fig. 4. Plate like structure formation was observed in $\alpha-\mathrm{Fe}_{2} \mathrm{O}_{3} \quad \mathrm{NPs}$ with homogeneous dispersion.
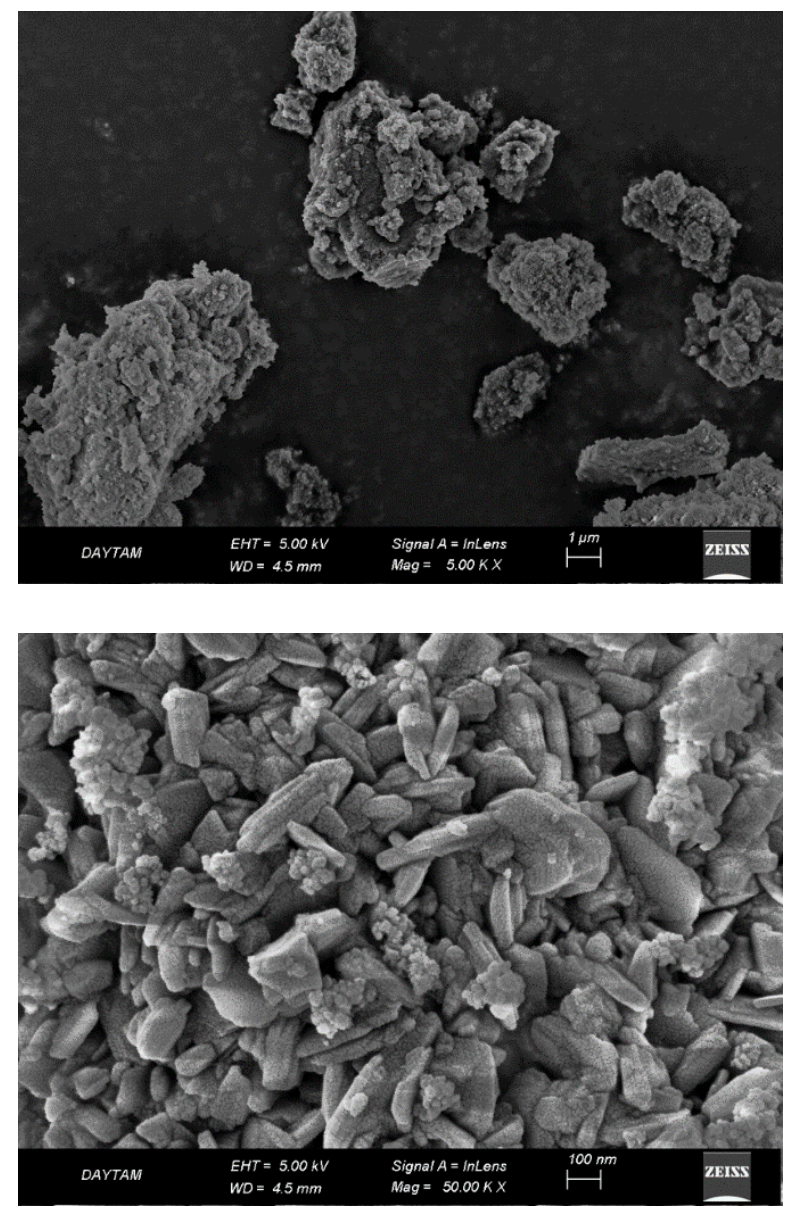

Figure 4. SEM images a) 5.00 KX Mag b) $50.00 \mathrm{KX}$ Mag for $\alpha-\mathrm{Fe}_{2} \mathrm{O}_{3}$
Figure 5 shows the optical absorption spectrum of the $\alpha-\mathrm{Fe}_{2} \mathrm{O}_{3} \mathrm{NPs}$, and the optical absorption feature was observed at wavelength between $380-540 \mathrm{~nm}$. The peak between $380-400 \mathrm{~nm}$ and the shoulder at 540 $\mathrm{nm}$ are originate from indirect $\mathrm{Fe} 3 \mathrm{~d}$ to $3 \mathrm{~d}$ and direct $\mathrm{O} 2 \mathrm{p}$ to Fe $3 \mathrm{~d}$ transitions (Taffa et al., 2015).

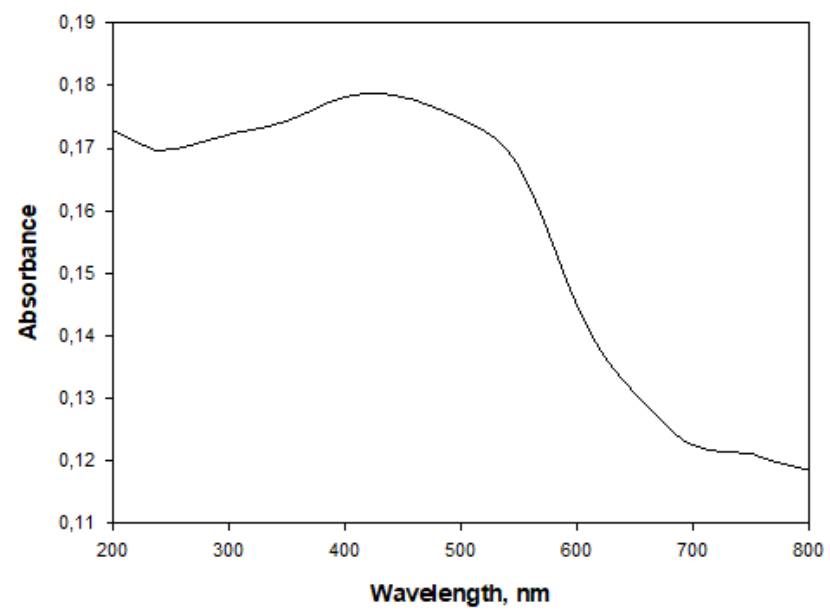

Figure 5. UV-Vis spectrum of $\alpha-\mathrm{Fe}_{2} \mathrm{O}_{3}$

In order to determine the optical band gap value of $\alpha-\mathrm{Fe}_{2} \mathrm{O}_{3} \mathrm{NPs}$, the optical data have been calculated by using Tauc Equation (4) (Tauc 1970).

$\alpha h v^{2}=\mathrm{A}(\mathrm{h} v-\mathrm{Eg})^{\mathrm{n}}$

where, the exponent $\mathrm{n}$ is a constant depending on the kind of optical transition, $\mathrm{A}$ is an effective mass constant, $h v$ is the energy of photons and $\mathrm{Eg}$ is the optical band gap. Owing to the indirect band transition in $\alpha-\mathrm{Fe}_{2} \mathrm{O}_{3}$, the value of $\mathrm{n}$ was taken as 2 (Kuhaili et al., 2012; Silva et al., 2013).

As shown in Fig.6, the optical band gap of the $\alpha-\mathrm{Fe}_{2} \mathrm{O}_{3}$ is $3.2 \mathrm{eV}$ and it has an inflection and shift to the red wavelength compared to that reported by Yoon et al. and Taffa et al. (Yoon et al., 2014; Taffa et al., 2015). 


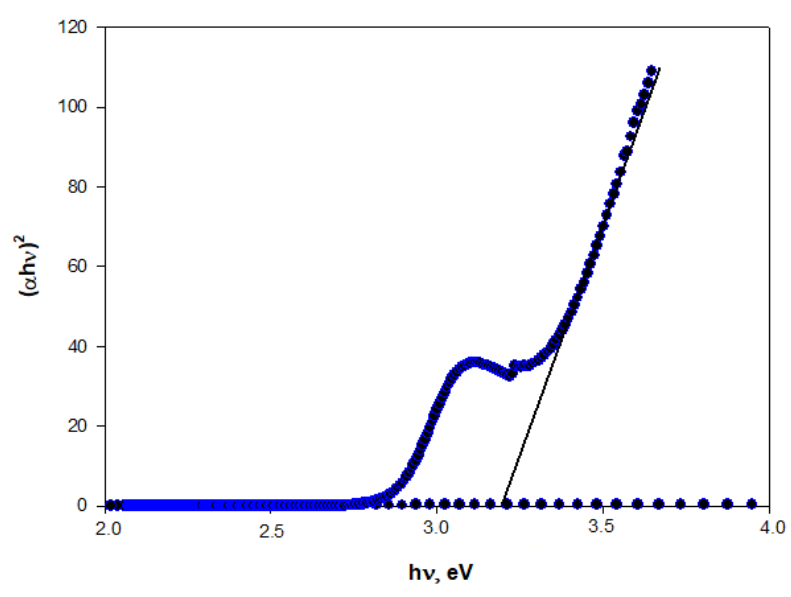

Figure 6. Tauc plot of $\alpha-\mathrm{Fe}_{2} \mathrm{O}_{3}$

\section{Conclusion}

In this study, $\alpha-\mathrm{Fe}_{2} \mathrm{O}_{3}$ NPs were synthesized by microemulsion method. The NPs showed the plate-like morphology. According to the XRD result, the formation of $\alpha-\mathrm{Fe}_{2} \mathrm{O}_{3} \mathrm{NPs}$ was observed. The crystallite size of the prepared $\alpha-\mathrm{Fe}_{2} \mathrm{O}_{3} \mathrm{NPs}$ was about $13.1 \mathrm{~nm}$. According to FTIR spectrum peaks of characteristic properties of $\alpha-\mathrm{Fe}_{2} \mathrm{O}_{3}$ were observed. In addition, TGA, DSC and DTG peaks are related to the transformation of amorphous phase to crystalline $\mathrm{Fe}_{2} \mathrm{O}_{3}$ and its transformation to $\alpha-\mathrm{Fe}_{2} \mathrm{O}_{3}$, respectively. Optical band gap of the obtained $\alpha-\mathrm{Fe}_{2} \mathrm{O}_{3} \mathrm{NPs}$ was found as $3.2 \mathrm{eV}$. Compared to the literature, $\alpha-\mathrm{Fe}_{2} \mathrm{O}_{3}$ NPs with a quite low particle size were obtained using the microemulsion method. Therefore, the microemulsion method is a very important method for the synthesis of nanoparticles.

\section{References}

Beygi, H. and Babakhani A. 2017. "Microemulsion Synthesis and Magnetic Properties of $\mathrm{Fe}_{\mathrm{x}} \mathrm{Ni}(1-\mathrm{x})$ Alloy Nanoparticles." Journal of Magnetism and Magnetic Materials, 421, 177-183.
Chen, L., Wenwen, K., Jincheng, Y., Bo, G., Qinan, Z., Haijun, B., Aimin, C. and Chunping, J. 2015a. "Effect of Sintering Temperature on Microstructure and Electrical Properties of $\mathrm{Mn}_{1.2} \mathrm{Co}_{1.5} \mathrm{Ni}_{0.3} \mathrm{O}_{4}$ Ceramic Materials Using Nanoparticles by Reverse Microemulsion Method." Journal of Materials Science: Materials in Electronics, 27(2), 1713-1718.

Chen, L., Wenwen, K., Jincheng, Y., Huimin, Z., Bo, G., Yonglei, L., Haijun, B., Aimin, C., Chunping, Ji. 2015b. "Synthesis and Characterization of $\mathrm{Mn}-\mathrm{Co}-\mathrm{Ni}-\mathrm{O}$ Ceramic Nanoparticles by Reverse Microemulsion Method." Ceramics International, 41(2), 2847-2851.

Foroughi, F., Hassanzadeh, T., Jamshid, A. 2015. "Microemulsion Synthesis and Magnetic Properties of HydroxyapatiteEncapsulated Nano $\mathrm{CoFe}_{2} \mathrm{O}_{4}$." Journal of Magnetism and Magnetic Materials, 382, 182-87.

Han, D. Y., Wang, C. Q., Li, D. D., Cao, Z. B. 2015. "NiO/ZnO Core-Shell Nanoparticles insitu synthesis via Microemulsion Method." Synthesis and Reactivity in Inorganic, MetalOrganic, and Nano-Metal Chemistry, 46(5), 794-797.

Kamali, K. Z., Alagarsamy, P., Huang, N. M., Ong B. H., Lim, H. N. 2014. "Hematite Nanoparticles-Modified Electrode Based Electrochemical Sensing Platform for Dopamine." IOP Conference Series: Materials Science and Engineering, 196, 396135-396139.

Khokhlova, T. D. 2017. "Adsorption of Proteins on $\gamma-\mathrm{Fe}_{2} \mathrm{O}_{3}$ and $\gamma-\mathrm{Fe}_{2} \mathrm{O}_{3} / \mathrm{SiO}_{2}$ Magnetic Materials." Russian Journal of Physical Chemistry A, 91(10), 1771-1775.

Koukabi, N., Kolvari, E., Khazaei, A., Zolfigol, M. A., Shaghasemic, B.S., Khavasi, H.R. 2011. "Hantzsch Reaction on Free Nano$\mathrm{Fe}_{2} \mathrm{O}_{3}$ Catalyst: Excellent Reactivity Combined with Facile Catalyst Recovery and Recyclability." Chemical Communications, 47, 9230-9232. 
Kuhaili, M. F., Saleem, M., Durrani, S. M. A. 2012. "Optical Properties of Iron Oxide $\alpha$ $\mathrm{Fe}_{2} \mathrm{O}_{3}$ ) Thin Films Deposited By the Reactive Evaporation of Iron." Journal of Alloys and Compounds, 521, 178-182.

Lai, W. C., Hong, L., Hsueh C.Y. 2019. "SizeTunable Silica Nanowires Prepared Using Reverse Microemulsion-Gel Systems." Journal of the Taiwan Institute of Chemical Engineers, 99, 207-214.

Laokul, P., Sathakan, A., Santi, M., Ekaphan, S. 2015. "Magnetic and Optical Properties of $\mathrm{CoFe}_{2} \mathrm{O}_{4}$ Nanoparticles Synthesized by Reverse Micelle Microemulsion Method." Journal of Superconductivity and Novel Magnetism, 28(8), 2483-2489.

Li, X., Honghao, Y., Xiangxin, X. 2016. "Extraction of Iron from Vanadium Slag Using Pressure Acid Leaching." Procedia Environmental Sciences, 31, 582-588.

Lin, B. Liaw, S. L. 2015. "Simultaneous Removal of Volatile Organic Compounds from Cooking Oil Fumes by Using Gas-Phase Ozonation over $\mathrm{Fe}(\mathrm{OH})_{3}$ Nanoparticles." Journal of Environmental Chemical Engineering, 3(3), 1530-1538.

Lu, Y. R., Wang, Y. F., Chang, H. W., Huang, Y. C., Chen, J. L., Chen, C. L., Lin, Y. C., Lin, Y. G., Pong, W. F., Ohigashi, T., Kosugi, N., Kuo, C. H., Chou, W. C., Dong, C. L. 2020. "Effect of $\mathrm{Fe}_{2} \mathrm{O}_{3}$ Coating on $\mathrm{ZnO}$ Nanowires in Photoelectrochemical Water Splitting: A Synchrotron X-Ray Spectroscopic and Spectromicroscopic Investigation." Solar Energy Materials, 209, 110469- 110475.

Mirzaei, A., Kamal, J., Babak, H., Seyyed, H., Maryam, B., Salvatore, L., Bonavita, A., and Giovanni, N. 2016. "Synthesis and Characterization of Mesoporous $\alpha-\mathrm{Fe}_{2} \mathrm{O}_{3}$ Nanoparticles and Investigation of Electrical Properties of Fabricated Thick Films." Processing and Application of Ceramics, 10(4), 209-217.

Najjar, R., Shokri, M., Farsadi, S. 2014. "Preparation of Pd-Doped $\mathrm{Nano}^{-\mathrm{TiO}_{2}}$ in Microemulsion and Their Application in Photodegradation of C.I. Acid Yellow 23."
Desalination and Water Treatment, 54(9), 2581-2591.

Patterson, A.L. 1939. "The Scherrer Formula for X-Ray Particle Size Determination." Physical Review, 56, 978-982.

Pournajaf, R., Hassanzadeh, S. A. T., Ghashang, M. 2014. "Effect of Surfactants on the Synthesis of $\mathrm{Al}_{2} \mathrm{O}_{3}-\mathrm{CeO}_{2}$ Nanocomposite Using a Reverse Microemulsion Method." Ceramics International, 40(3), 4933-4937.

Pournajaf, R. Hassanzadeh, S. A. T. 2015. "Effect of Heat Treatment on the Size, Structural and Catalytic Properties of $\mathrm{Al}_{2} \mathrm{O}_{3}-$ $\mathrm{CeO}_{2}$ Nanocomposite Powder Prepared by Microemulsion Method." Journal of Sol-Gel Science and Technology, 75(2), 360-365.

Sarkar, D., Sonia, T., Vikram, T., Raman, S. S., Kartic, C. K. 2011. "Formation of Zinc Oxide Nanoparticles of Different Shapes in Water-in-Oil Microemulsion." Colloids and Surfaces A: Physicochemical and Engineering Aspects, 381(1-3), 123-129.

Shiri, M. S. Z., Henderson, W., Mucalo M. R. 2019. "A Review of the Lesser-Studied Microemulsion-Based Synthesis Methodologies Used for Preparing Nanoparticle Systems of the Noble Metals, Os, Re, Ir and Rh." Materials, 12, 1896-1921.

Shojaei, S., Hassanzadeh S. A. T., Ghashang, M. 2014. "Reverse Microemulsion Synthesis and Characterization of $\mathrm{CaSnO} 3$ Nanoparticles." Ceramics International, 40(7), 9609-9613.

Silva, M. F., Oliveira, L. A. S., Ciciliati, M. A., Silva, L. T., Pereira, B. S., Hechenleitner, A. A., Oliveira, M. F. et al. 2013. "Nanometric particle size and phase controlled synthesis and characterization of $\gamma$ $\mathrm{Fe}_{2} \mathrm{O}_{3}$ or $(\alpha+\gamma)-\mathrm{Fe}_{2} \mathrm{O}_{3}$ by a modified sol-gel method." Journal of Applied Physics, 114, 104311-104318

Strom, L., Strom, H., Carlsson, P. A., Skoglundh, M., Harelind, H. 2018. "Catalytically Active Pd-Ag Alloy Nanoparticles Synthesized in Microemulsion Template." Langmuir, 34(33), 9754-9761. 
Taffa, D. H., Hamm, I., Dunkel, C., Sinev, I., Bahnemanncd D., Wark, M. 2015. "Electrochemical deposition of $\mathrm{Fe}_{2} \mathrm{O}_{3}$ in the presence of organic additives: a route to enhanced photoactivity." RSC Advances, 5, 103512-103522.

Tauc J, Grigorovici R, Vancu A. 1966. "Optical Properties and Electronic Structure of Amorphous Germanium." Phys Status Solidi (b), 15, 627-637.

Wang, Z., Zhang, K., Fei, T., Gu, F., Han, D. 2020. " $\alpha-\mathrm{Fe}_{2} \mathrm{O}_{3} /$ Nio Heterojunction Nanorods With Enhanced Gas Sensing Performance for Acetone." Sensors and Actuators B: Chemical, 318, 128191-128199.

Waseem, M. S., Naeem, M. A., Shah K. H., Rashid, U. 2013. "Synthesis, Physical Characteristics, and $\mathrm{Cd}^{2+}$ Sorption Studies of Amorphous $\mathrm{Fe}(\mathrm{OH})_{3}$." Desalination and Water Treatment, 52(25-27), 4783-4791.

Xiang, H., Ren, G., Yang, X., Xu,D., Zhang, Z., Wang, X. 2020. "A Low-Cost SolventFree Method to Synthesize $\alpha-\mathrm{Fe} 2 \mathrm{O} 3$ Nanoparticles with Applications to Degrade Methyl Orange in Photo-Fenton System." Ecotoxicology and Environmental Safety, 200, 110744-110749.

Ye, H., Wang, J. Wang W. H., Bao, M. 2018. "Encapsulation of Pd Sub-Nanoclusters in $\mathrm{SiO}_{2}$ Nanospheres by a Reverse Microemulsion Method." Functional Materials Letters, 11(04), 1850081-1850084.

Yoon, K. Y., Lee, J. S., Kim, K., Bak, C. H., Kim, S. I., Kim, J. B., Jang, J. H. 2014. "Hematite-Based Photoelectrochemical Water Splitting Supported by Inverse Opal Structures of Graphene." ACS Applied Materials Interfaces, 6(24):22634-22639.

Zainuri, M. 2017. "Hematite from Natural Iron Stones as Microwave Absorbing Material on X-Band Frequency Ranges." IOP Conference Series: Materials Science and Engineering, 196, 012008-0120012. 